\title{
Reflector and Pragmatic Learning Styles in Learning Value Clarification Technique (VCT) and Direct Instruction (DI)
}

\author{
Sri Yunita ${ }^{1}$, Abdul Hamid K ${ }^{2}$, Hamonangan Tambunan ${ }^{3}$ \\ ${ }^{1,2,3}$ Educational Technology Study Program, Universitas Negeri Medan, Indonesia \\ sriyunitasugiharto@gmail.com
}

\begin{abstract}
This study used a quasi-experimental research type (quasiexperimental) with a $2 \times 2$ factorial design. The research sample was taken by cluster random sampling where one group was treated with the VCT learning model with a sample size of 50 people and one group was treated with the DI learning model with the number of a sample of 51 people. The data collection instruments used were Civics learning outcomes test and learning style questionnaire. The results of hypothesis testing conclude that: 1) There is an influence of the interaction between the learning model and student learning styles on learning outcomes, 2) the learning outcomes of students who have a reflector learning style learned with the VCT learning model are higher than those taught with the DI learning model.
\end{abstract}

Keywords

reflector learning style; pragmatic learning style; value clarification technique learning, direct instruction learning

\section{Introduction}

Citizenship Education (Civics) is a subject that is required in the curriculum starting from elementary to tertiary education. This is given the importance of the role of this subject as an effort to develop abilities and shape the character of the next generation of the nation to become individuals with noble character and become democratic and responsible citizens. Citizenship Education is one of the important subjects that play a major role in realizing the goals of national education as outlined in Law No.20 of 2003 concerning the National Education System, namely:

"National education has the function of developing abilities and shaping the character and civilization of a nation with dignity in order to educate the nation's life, aiming to develop the potential of students to become human beings who believe and have devotion to God Almighty, have noble character, are healthy, knowledgeable, capable, creative, and independent and become citizens who are democratic and responsible (Depdiknas, 2003: 8)

Value education is formulated from two words education and value. Each word has a different meaning. Education has a meaning as a process, so education is not just preparing learners to be able to live in today's society, but they also have to be prepared for the future life like UNESCO concept, that learning is to know, to do, to be, and live together. It means education is not just for knowledge, work, but the ability to live together. With education a child has a life, adjusts, and is able to face the challenges of a dynamic era. (Khairiah, $\mathrm{N}$ and Nurzannah)

Citizenship Education (PPKn) is one of the subjects considered to be involved in shaping the personality of students. Susanto (2013: 225), Citizenship Education is a subject that is used as a vehicle to develop and preserve noble and moral values that are rooted in Indonesian culture. Whereas in the Competency Based Curriculum (2004) it is explained 
that Citizenship Education is a subject that focuses on the formation of diverse self in terms of religion, socio-culture, language, age and ethnicity to become citizens who are intelligent, skilled, and characterized by the Pancasila and the 1945 Constitution. (Ginting, et al. 2020).

For this reason Citizenship Education (civics education) must be implemented from an early age, so that Indonesian citizens are able to form quality and responsible participatory skills in political and social life at the local, national, regional and global levels that are able to make Indonesian citizens become good citizens of society who are able to maintain the unity and integrity of the nation in order to create an Indonesia that is strong, prosperous and democratic, and is able to produce students who think comprehensively, analytically, critically and act democratically.

However, in reality Citizenship Education, which has been included in the curriculum since 1962, is considered to have not succeeded in having a positive impact in shaping behavior as good citizens. The Civics lessons that have been going on so far have not succeeded in creating moral and ethical human beings according to their mission and goals. The spread of collusive practices, corruption and a culture of nepotism, political behavior and actions of state officials deviates greatly from what he has always said so far. This makes Civics as a subject increasingly discredited (Narmoatmojo, 2010).

Medan State University (Unimed) as one of the Higher Education Institutions (LPTK) which has the task of forming the nation's next generation who have knowledge and skills in their respective fields so that they are ready to take part and benefit the community. Apart from knowledge and skills, character building is a major concern. In accordance with Unimed's slogan, The Character Building University, Unimed continues to strive to improve the quality of graduate students who are not only skilled in their fields but also have noble character.

One of the efforts made is to make the Citizenship Education course a compulsory subject for all majors. Citizenship Education is a course that focuses on forming citizens who understand and are able to exercise their rights and obligations to become smart, skilled and character Indonesian citizens mandated by Pancasila and the 1945 Constitution (Permendiknas, 2006).

Even though the Civics course is a compulsory subject and plays an important role in character building, in fact the Civics course is one of the subjects considered by most students to be not so important, too easy, boring or monotonous because it has been studied even since elementary school. This impression increases when many Civics educators or lecturers deliver lessons in the same boring way.

\section{Research Methods}

This research refers to a quantitative research approach.This research was conducted on two sample groups, namely the sample group that was applied the VCT learning model and the group that applied the DI learning model. Although both groups were controlled by the learning model treatment, there were other factors that influenced student civics learning outcomes that the researcher could not control, such as initial knowledge, study habits at home, etc. Therefore, the right type of research is quasi experiment.

This research was conducted in the Department of Citizenship Education, Faculty of Social Sciences, State University of Medan (FIS UNIMED). The implementation is carried out on students in the first semester of the 2016 academic year (TA), starting from August to November 2016. 
The population reached by this study were 150 students in the first semester (one) of the Citizenship Education Study Program. The population spreads to 5 (five) classes. These students have never attended a lecture on the subject matter / topic being studied. Thus, the teaching message is new knowledge for all members of the research subject.

The sample was taken by using cluster random sampling technique. The sampling technique was carried out by raffling the class sample to determine which class was treated with the VCT model and which class was treated with the Direct Instruction model. The sample class is only grouped based on treatment, and not grouped based on learning styles. One class was given VCT model treatment and one class was given Direct Instruction treatment with the assumption that each type of learning style existed in each sample class.

The research was conducted using a quasi-experimental method. The independent variable is a learning model. The experimental design used was a $2 \times 2$ factorial design. The independent variable of the study was the learning model, namely the VCT learning model and the DI learning model. Moderator variables that affect learning outcomes are learning styles, namely reflector learning styles and pragmatic learning styles.

These variables will then be reviewed in a research design as shown in Table 3.1. Following.

Table 1. Research Design Matrix 2 x 2 Factorial Design

\begin{tabular}{lcc}
\hline Learning Style (B) & \multicolumn{2}{c}{ Learning Model (A) } \\
\cline { 2 - 3 } & $\mathrm{VCT}(\mathrm{A} 1)$ & $\mathrm{IN}(\mathrm{A} 2)$ \\
\hline Reflector (B1) & $\mu \mathrm{A} 1 \mathrm{~B} 1$ & $\mu \mathrm{A} 2 \mathrm{~B} 1$ \\
\hline Pragmatic (B2) & $\mu \mathrm{A} 1 \mathrm{~B} 2$ & $\mu \mathrm{A} 2 \mathrm{~B} 2$ \\
\hline
\end{tabular}

Information:

$\mu \mathrm{A} 1 \mathrm{~B} 1$ : The average learning outcomes for groups of students who have a reflector learning style and are taught using the VCT learning model

$\mu \mathrm{A} 1 \mathrm{~B} 2$ : The average learning outcomes for groups of students who have a pragmatic learning style and are taught using the VCT model

$\mu \mathrm{A} 2 \mathrm{~B} 1$ : The average learning outcomes of groups of students who have a reflector learning style and are taught using the Direct Instruction learning model

$\mu \mathrm{A} 2 \mathrm{~B} 2$ : The average learning outcomes for groups of students who have a pragmatic learning style and are taught using the Direct Instruction model

$\mu \quad$ : Average learning outcomes

Before carrying out the treatment, learning tools such as syllabus, lesson plans, and lecture contracts are prepared which are integrated with the learning models to be used, namely VCT and DI. Next, prepare the sources, tools and materials needed for each treatment. In general, the implementation of the VCT learning model can be seen in Table 2. as follows: 
Table 2. Implementation of VCT Learning Model Treatment

\begin{tabular}{|c|c|c|c|}
\hline Step & Phase & Lecturer Activities & Student Activities \\
\hline \multirow[t]{2}{*}{ Opener } & $\begin{array}{l}\text { Self } \\
\text { Evaluation }\end{array}$ & 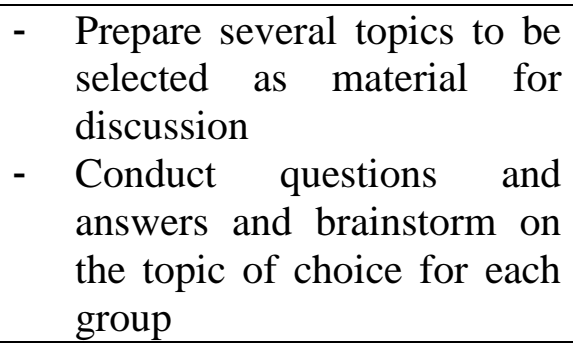 & $\begin{array}{l}\text { - Choose a topic } \\
\text { - Convey ideas and ideas } \\
\text { about the topic of choice } \\
\text { and the reasons for } \\
\text { choosing the topic }\end{array}$ \\
\hline & Lecturing & $\begin{array}{l}\text { - Convey an outline of the } \\
\text { material } \\
\text { - Explain discussion signs and } \\
\text { assignments that students } \\
\text { must complete } \\
\text { - Guide the discussion }\end{array}$ & - Listen to explanations \\
\hline \multirow[t]{2}{*}{ Contents } & $\begin{array}{l}\text { Setting an } \\
\text { example }\end{array}$ & $\begin{array}{l}\text { - Guiding students to find } \\
\text { examples that come from } \\
\text { students or the wider } \\
\text { community } \\
\text { - Guiding and directing } \\
\text { students in making } \\
\text { conclusions on the analysis } \\
\text { and assessment of examples }\end{array}$ & $\begin{array}{l}\text { - Discuss in groups to find } \\
\text { examples in everyday life } \\
\text { - Analyze and assess the } \\
\text { examples given }\end{array}$ \\
\hline & Indoctrination & $\begin{array}{l}\text { - Convey values that should } \\
\text { be believed and practiced by } \\
\text { students }\end{array}$ & - Listen to explanations \\
\hline \multirow[t]{3}{*}{ Closing } & Dialog & $\begin{array}{l}\text { - Provide opportunities for } \\
\text { students to provide } \\
\text { questions, responses and } \\
\text { their opinions about the } \\
\text { material and the values } \\
\text { contained }\end{array}$ & $\begin{array}{l}\text { Provide questions, } \\
\text { responses and opinions on } \\
\text { the material and values } \\
\text { contained }\end{array}$ \\
\hline & Inference & $\begin{array}{l}\text { - Providing opportunities for } \\
\text { students to conclude for } \\
\text { themselves the learning } \\
\text { received and the values } \\
\text { contained therein }\end{array}$ & $\begin{array}{l}\text { - Reflecting on the material } \\
\text { that has been studied and } \\
\text { the values that are } \\
\text { believed, and is } \\
\text { determined to practice the } \\
\text { values that have been } \\
\text { learned }\end{array}$ \\
\hline & Assignment & $\begin{array}{l}\text { - Give the task of assessing a } \\
\text { piece of writing }\end{array}$ & - Doing chores at home \\
\hline
\end{tabular}

Furthermore, the implementation of the Direct Instruction learning model can be seen in Table 3 as follows: 
Table 3. Implementation of Direct Instruction Learning Model Treatment

\begin{tabular}{|c|c|c|c|}
\hline Step & Phase & Lecturer Activities & Student Activities \\
\hline Opener & Orientation & $\begin{array}{l}\text { - } \begin{array}{l}\text { Determine the subject } \\
\text { matter }\end{array} \\
\text { - } \begin{array}{l}\text { Review previous lessons } \\
\text { - }\end{array} \\
\begin{array}{l}\text { Determine learning } \\
\text { objectives }\end{array} \\
\text { - } \begin{array}{l}\text { Determine the learning } \\
\text { procedure }\end{array}\end{array}$ & - $\quad$ Listen \\
\hline \multirow[t]{3}{*}{ Contents } & Presentation & 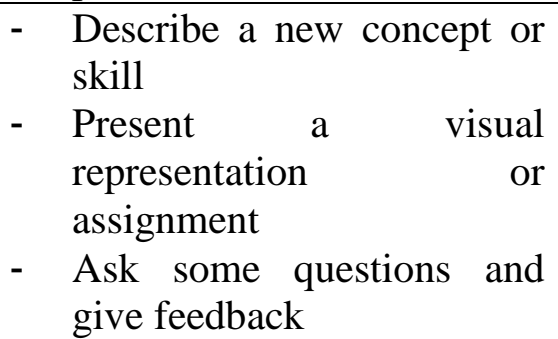 & $\begin{array}{l}\text { - } \begin{array}{l}\text { Listening and paying } \\
\text { attention }\end{array} \\
\text { - Give answers and } \\
\text { responses }\end{array}$ \\
\hline & $\begin{array}{l}\text { Structured } \\
\text { practice } \\
\text { (demonstration) }\end{array}$ & $\begin{array}{l}\text { - Guide the group by } \\
\text { practical examples in } \\
\text { several steps } \\
\text { - } \\
\text { Do interactive question and } \\
\text { answer } \\
\text { - } \text { Give feedback }\end{array}$ & $\begin{array}{l}\text { - } \text { Pay attention } \\
\text { - Ask questions, answer } \\
\text { questions or respond }\end{array}$ \\
\hline & Guided practice & 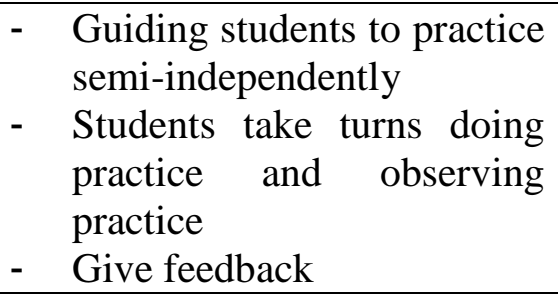 & $\begin{array}{l}\text { - Work in groups } \\
\text { - } \quad \text { Presenting } \\
\text { - } \quad \text { Give and answer questions }\end{array}$ \\
\hline Closing & $\begin{array}{l}\text { Independent } \\
\text { practice }\end{array}$ & $\begin{array}{l}\text { - Giving independent tasks } \\
\text { for students } \\
\text { - Educators postpone } \\
\text { feedback and provide it at } \\
\text { the end of the learning } \\
\text { series } \\
\text { - Give independent } \\
\text { assignments several times }\end{array}$ & - $\quad$ Doing independent tasks \\
\hline
\end{tabular}




\section{Results and Discussion}

\subsection{Description of Research Data}

Data on student civics learning outcomes treated with VCT learning models and treated with DI learning models and their learning styles can be seen in the appendix. The summary of student learning outcomes data with reflector and pragmatic learning styles that are taught using the VCT and DI learning models is presented in Table 4 below:

Table 4. Summary of Descriptive Statistics Calculation of Student Learning Outcomes

\begin{tabular}{|c|c|c|c|c|}
\hline \multirow{2}{*}{\multicolumn{2}{|c|}{ Learning Style (B) }} & \multicolumn{2}{|c|}{ Learning Model (A) } & \multirow{3}{*}{\begin{tabular}{|c|} 
Total \\
51 \\
\end{tabular}} \\
\hline & & $\mathrm{VCT}(\mathrm{A} 1)$ & IN (A2) & \\
\hline \multirow[t]{8}{*}{ Refector (B1) } & $\mathrm{n}$ & 26 & 25 & \\
\hline & $\mathrm{M}$ & 35.58 & 27.04 & 31.48 \\
\hline & Mo & 35.00 & 27.00 & 30.00 \\
\hline & $\mathrm{Me}$ & 36.00 & 28.00 & 32.00 \\
\hline & $\mathrm{Sd}$ & 3.10 & 4.88 & 5.90 \\
\hline & Var & 9.62 & 23.79 & 34.82 \\
\hline & Min & 30 & 15 & 15.0 \\
\hline & Max & 40 & 34 & 40.0 \\
\hline \multirow[t]{8}{*}{ Pragmatic (B2) } & $\mathrm{n}$ & 24 & 26 & 50 \\
\hline & $\bar{M}$ & 30.63 & 32.27 & 31.42 \\
\hline & Mo & 33.00 & 35.00 & 33.00 \\
\hline & $\mathrm{Me}$ & 31.50 & 33.00 & 32.50 \\
\hline & $\mathrm{Sd}$ & 5.17 & 5.31 & 5.25 \\
\hline & Var & 26.70 & 28.19 & 27.58 \\
\hline & Min & 22 & 21 & 21.0 \\
\hline & Max & 39 & 39 & 39.0 \\
\hline \multirow[t]{8}{*}{ Total } & $\mathrm{N}$ & 50 & 51 & \\
\hline & $\mathrm{M}$ & 33.08 & 29.75 & \\
\hline & Mo & 35.00 & 27.00 & \\
\hline & $\mathrm{Me}$ & 34.00 & 30.00 & \\
\hline & $\mathrm{Sd}$ & 4.88 & 5.68 & \\
\hline & Var & 23.81 & 32.29 & \\
\hline & Min & 22 & 15 & \\
\hline & Max & 40 & 39 & \\
\hline
\end{tabular}

Information:
A $\quad=$ Learning Model
B = Learning Style
A1 = VCT Learning Model
A2 = DI Learning Model
B1 = Reflector Learning Style
B2 = Pragmatic Learning Style 


\subsection{Testing Requirements Analysis}

Before the hypothesis is tested, it is necessary to test the data analysis requirements. The data requirements needed to test the hypothesis are data that is normally distributed and homogeneous so that the research results can be accounted for by research if the sample is taken randomly (random sampling). Test data analysis requirements using spss.

\section{a. Normality Test}

The summary of calculations can be seen in Table 4 below:

Table 5. Data Normality Test Results

\begin{tabular}{|c|l|c|c|c|c|}
\hline $\begin{array}{c}\text { No } \\
.\end{array}$ & \multicolumn{1}{|c|}{ Group } & $\begin{array}{c}\text { Statistic } \\
\text { s }\end{array}$ & df & Sig. & Info \\
\hline 1 & $\begin{array}{l}\text { Student learning outcomes who are } \\
\text { taught the VCT model }\end{array}$ & 0.113 & 50 & 0.139 & Normal \\
\hline 2 & $\begin{array}{l}\text { Student learning outcomes that are } \\
\text { taught using the DI model }\end{array}$ & 0.069 & 51 & 0.200 & Normal \\
\hline 3 & $\begin{array}{l}\text { Learning outcomes of students who } \\
\text { have a pragmatic learning style }\end{array}$ & 0.124 & 50 & 0.053 & Normal \\
\hline 4 & $\begin{array}{l}\text { Learning outcomes of students who } \\
\text { have a reflector learning style }\end{array}$ & 0.087 & 51 & 0.200 & Normal \\
\hline 5 & $\begin{array}{l}\text { The learning outcomes of students } \\
\text { who have a pragmatic learning style } \\
\text { are taught using the VCT model }\end{array}$ & 0.940 & 24 & 0.163 & Normal \\
\hline 6 & $\begin{array}{l}\text { The learning outcomes of students } \\
\text { who have a reflector learning style } \\
\text { are taught using the VCT model }\end{array}$ & 0.937 & 26 & 0.112 & Normal \\
\hline 7 & $\begin{array}{l}\text { The learning outcomes of students } \\
\text { who have a pragmatic learning style } \\
\text { are taught using the DI model }\end{array}$ & 0.929 & 26 & 0.072 & Normal \\
\hline 8 & $\begin{array}{l}\text { The learning outcomes of students } \\
\text { who have a reflector learning style } \\
\text { are taught using the DI model }\end{array}$ & 0.936 & 25 & 0.117 & Normal \\
\hline
\end{tabular}

\section{b. Homogeneity Test}

The homogeneity test was carried out using the SPSS application. The calculation results can be seen in Table 5 below:

Table 6. Homogeneity Test Results

\begin{tabular}{|c|l|c|c|c|}
\hline No. & \multicolumn{1}{|c|}{ Group } & $\begin{array}{l}\text { Levene } \\
\text { Statistics }\end{array}$ & Sig. & Information \\
\hline $\mathbf{1}$ & $\begin{array}{l}\text { Student groups treated with different } \\
\text { learning models }\end{array}$ & 1,254 & 0.266 & Homogeneous \\
\hline $\mathbf{2}$ & $\begin{array}{l}\text { Groups of students with different } \\
\text { learning styles }\end{array}$ & 0.247 & 0.620 & Homogeneous \\
\hline $\mathbf{3}$ & $\begin{array}{l}\text { Student groups treated with different } \\
\text { learning models and learning styles }\end{array}$ & 2,334 & 0.079 & Homogeneous \\
\hline
\end{tabular}




\section{c. Hypothesis test}

Testing the research hypothesis in this study is related to interaction testing, namely whether there is an interaction between learning models and learning styles on learning outcomes. The technique used to test the hypothesis is to use two-way analysis of variance assisted by the SPSS application.

Based on the calculation, it is found that there is an interaction between the learning model and the learning style as evidenced by the acquisition of $F=13.82$ and the value of Sig. $=0<0.05$, so the calculation is continued with the Scheffe test. The summary of the Scheffe test results can be seen in Table 6 below:

Table 7. Scheffe Test Results

\begin{tabular}{|c|c|c|c|}
\hline Criteria & Hypothesis & Sig & Information \\
\hline \multirow{2}{*}{$\begin{array}{l}\text { Reject H0 if } \\
\text { Sig. }<0.05\end{array}$} & $\begin{array}{l}\mathrm{H} 0: \mu \mathrm{A} 1 \mathrm{~B} 1 \leq \mu \mathrm{A} 2 \mathrm{~B} 1 \\
\mathrm{H} 1: \mu \mathrm{A} 1 \mathrm{~B} 1>\mu \mathrm{A} 2 \mathrm{~B} 1\end{array}$ & 0 & $\begin{array}{l}\mathrm{H} 0 \text { is rejected (there is a significant } \\
\text { difference) }\end{array}$ \\
\hline & $\begin{array}{l}\mathrm{H} 0: \mu \mathrm{A} 1 \mathrm{~B} 2 \leq \mu \mathrm{A} 2 \mathrm{~B} 2 \\
\mathrm{H} 1: \mu \mathrm{A} 1 \mathrm{~B} 2>\mu \mathrm{A} 2 \mathrm{~B} 2\end{array}$ & 0.687 & $\begin{array}{l}\mathrm{H} 0 \text { is accepted (there is no } \\
\text { significant difference) }\end{array}$ \\
\hline \multirow[t]{2}{*}{$\begin{array}{l}\text { Accept H0 if } \\
\text { Sig. }>0.05\end{array}$} & $\begin{array}{l}\mathrm{H} 0: \mu \mathrm{A} 1 \mathrm{~B} 1 \leq \mu \mathrm{A} 1 \mathrm{~B} 2 \\
\mathrm{H} 1: \mu \mathrm{A} 1 \mathrm{~B} 1>\mu \mathrm{A} 1 \mathrm{~B} 2\end{array}$ & 0.004 & $\begin{array}{l}\mathrm{H} 0 \text { is rejected (there is a significant } \\
\text { difference) }\end{array}$ \\
\hline & $\begin{array}{l}\mathrm{H} 0: \mu \mathrm{A} 2 \mathrm{~B} 1 \leq \mu \mathrm{A} 2 \mathrm{~B} 2 \\
\mathrm{H} 1: \mu \mathrm{A} 2 \mathrm{~B} 1>\mu \mathrm{A} 2 \mathrm{~B} 2\end{array}$ & 0.002 & $\begin{array}{l}\mathrm{H} 0 \text { is rejected (there is a significant } \\
\text { difference) }\end{array}$ \\
\hline
\end{tabular}

\section{The Effect of the Interaction between Learning Models and Learning Styles on Student Pkn Learning Outcomes}

Based on the results of hypothesis testing, the value of $F=13.824$ and the value of Sig. $0<0.05$, so that Ho is rejected and Ha is accepted. Thus there is an influence of the interaction effect between learning models and student learning styles. The interaction between learning models and learning styles can be seen in Figure 1.The following:

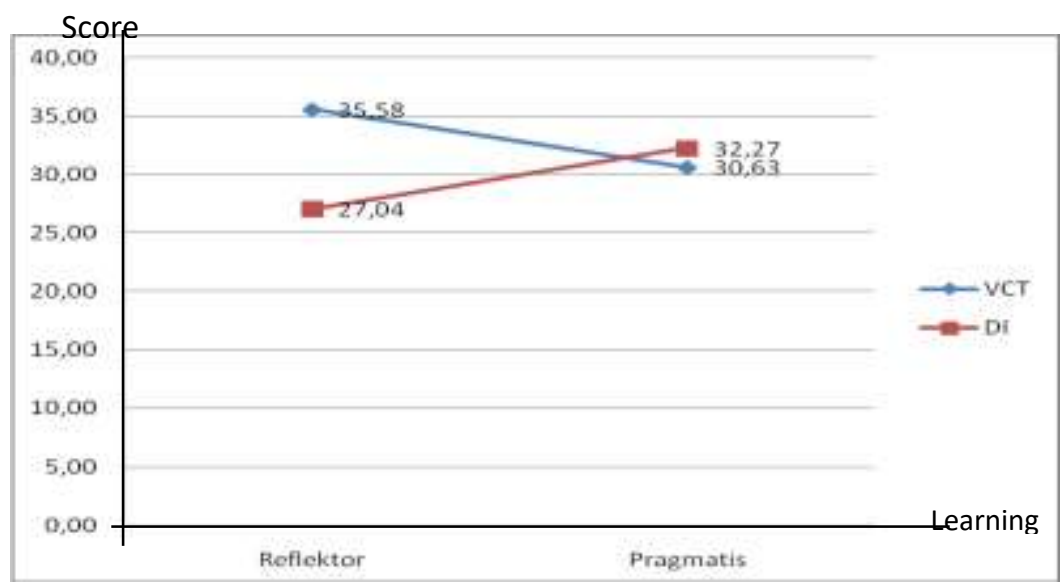

Figure 1. Graph of the Interaction of Learning Models and Learning Styles on Civics Learning Outcomes

Based on Figure 4.9. Above, it can be seen that there is an interaction between learning models and learning styles, in this case students with reflector learning styles are more appropriately taught using the VCT learning model while students with pragmatic learning styles are more appropriately taught using the DI learning model. It can be seen that the average score obtained by students with a reflector learning style in the VCT class 
is higher than in the DI class, while the average score of students with a pragmatic learning style in the DI class is higher than in the VCT class.

\section{Differences in Pkn Learning Outcomes of Students Who Have Reflector Learning Styles who are taught with the Value Clarification Technique Learning Model compared to those taught with the Direct Instruction Model}

Based on the results of hypothesis testing, the Sig. $0<0.05$, so that Ho is rejected and $\mathrm{H} 1$ is accepted. Thus there is a significant difference in student learning outcomes with the reflector learning style treated with the VCT learning model and those treated with the DI learning model. Observing the average learning outcomes of students who have a reflector learning style who are treated with the VCT learning model (35.58) are higher than the average learning outcomes of students with a reflector learning style treated with the DI learning model (27.04), it can be It is said that the learning outcomes of students with the reflector learning style that are taught with the VCT learning model are higher than those taught with the DI learning model which is true.

3. Differences in Pkn Learning Outcomes of Students Who Have a Pragmatic Learning Style taught by the Value Clarification Technique Learning Model compared to those taught with the Direct Instruction Model

Based on the results of hypothesis testing, the Sig. 0.687> 0.05, so that Ho is accepted and $\mathrm{H} 1$ is rejected. Thus there is no significant difference in student learning outcomes with pragmatic learning styles treated with the VCT learning model and those treated with the DI learning model. Observing the average learning outcomes of students who have a pragmatic learning style who are treated with the VCT learning model (30.63) are lower than the average learning outcomes of students with pragmatic learning styles treated with the DI learning model (32.27) but the difference is not significant,

\section{Differences in Learning Outcomes for Reflector Students and Pragmatic Students who are taught by the Value Clarification Technique Learning Model}

Based on the results of hypothesis testing, the Sig. $0.004<0.05$, so that Ho is rejected and $\mathrm{H} 1$ is accepted. Thus there is a significant difference in student learning outcomes with reflector learning styles and students with pragmatic learning styles who are treated with the VCT learning model. Observing the average learning outcomes of students who have a reflector learning style treated with VCT learning models (35.58) are higher than the average learning outcomes of students with pragmatic learning styles treated with VCT learning models (30.63), it can be It is said that the learning outcomes of students with reflector learning styles are higher with the learning outcomes of students with pragmatic learning styles that are taught using the VCT learning model which is validated.

\section{Differences in Learning Outcomes for Reflector Students and Pragmatic Students who are taught by the Direct Instruction Model}

Based on the results of hypothesis testing, the Sig. $0.002<0.05$, so that Ho is rejected and $\mathrm{H} 1$ is accepted. Thus there is a significant difference in student learning outcomes with reflector learning styles and students with pragmatic learning styles treated with the DI learning model. Observing the average learning outcomes of students who have a pragmatic learning style who are treated with the DI learning model (32.27) are higher than the average learning outcomes of students with reflector learning styles treated with the DI learning model (27.04), it can be It is said that the learning outcomes of students with a 
pragmatic learning style are higher with the learning outcomes of students with a reflector learning style taught using the DI learning model.

\subsection{Research Discussion}

The discussion of the results of this study discusses the relationship between data and fact findings obtained from the results of hypothesis testing, especially in relation to the theory used.

\section{a. The Effect of the Interaction between Learning Models and Learning Styles on Learning Outcomes of Pkn}

Based on the results of the hypothesis test, it was found that there was an interaction between the learning model and learning styles on student civics learning outcomes. The discussion on the results of the hypothesis test is described as follows. Learning outcomes can be improved by accommodating a variety of potentials that exist in students, including learning styles. The lecturers' knowledge of the characteristics of these students becomes a material for consideration for lecturers in choosing methods, teaching techniques, and teaching materials that are in accordance with the diversity of learning styles of students.

Educators need to understand their students in the implementation of learning in the classroom by considering the dominant learning styles that their students have. Inaccurate selection of strategies and learning models used resulted in learning objectives that were expected not to be achieved optimally. Considering the learning styles in the selection of learning methods and strategies used are considered effective enough to improveachievement of learning objectives. This is because the suitability of the chosen strategy and the learning styles of the students provide many positive things that can be achieved optimally such as a pleasant learning atmosphere, learning motivation and student interest increases, and learning outcomes are also increasing.

On the other hand, Davis (1989: 45) states that if the learning styles of educators and the learning styles of students are not appropriate, it will make both parties dissatisfied and frustrated. Improper strategies, make learning ineffective, maybe even can hinder students from learning. Knowing learning styles can help a person to: (1) learn more effectively, (2) learn how to develop and use their learning strengths more effectively, (3) develop additional learning skills, (4) understand their natural tendency to organize and use information in making decisions, (5) predict how they can respond to challenges, (6) decide how best to contribute to the team, (7) develop their careers (Nasution: 2008).

Prashnig (2007: 107) also suggests that the results of the identification of learning styles can also be used by teachers to: (1) understand the diversity of students in the classroom, (2) improve communication with students / parents, (3) help design appropriate classrooms with the learning needs of students, (4) increasing interaction between students and teachers, (5) matching learning and teaching styles, (6) being used to handle students at risk, (7) reducing stress in difficult situations, and (8) improve teaching performance and increase job satisfaction. Based on the explanation above, it can be concluded that there is an influence of the interaction between learning models and learning styles in influencing student civics learning outcomes. 
b. Differences in Civics Learning Outcomes of Students Who Have a Reflector Learning Style Taught with the VCT Learning Model compared to those Taught with the Direct Instruction Model

Based on the results of the hypothesis test, it is concluded that the learning outcomes of reflector-type Civics students who are taught with the VCT learning model are higher than the reflector-type student learning outcomes. There is an interaction between learning models and learning styles on student Civics learning outcomes. The discussion on the results of the hypothesis test is described as follows.

Students with the reflector type of learning style are students who have good powers of observation and thinking power. They like to be involved in research, investigations, information gathering and enjoy finding the root of problems. When in group activities, this type tends to prefer paying attention, listening to and observing discussion activities. This type does not like being pressed for time and working under pressure and doing things without planning. They also don't like being the center of attention.

This type is more adaptable in the VCT learning environment. In VCT learning, there are many stages where students are given the opportunity to think deeply, reflect on themselves, especially in understanding the values that are implanted in each stage of learning. In addition, each stage also provides an opportunity for students to gather more information about the material being studied. This is in accordance with the type of reflector who does not like to rush to make decisions and conclude something without sufficient data and information.

For example, at the sampling stage, where the lecturer gives examples of cases and problems. These cases and problems are discussed and reflected in the values considered by students themselves through deep thinking.

Furthermore, in the indoctrination stage where the lecturer provides views about the values that exist in society, about the values that should be instilled in students. At this stage also, students are given the opportunity to think about the values they have adopted so far, whether they are appropriate or they have to think and reflect on the values they hold.

Furthermore, at the stage of assessing written material, it is one of the tasks given in VCT learning. In this stage, students are assigned to review, comment on and assess an article / book / journal as well as identify the values contained in the writing. This stage is very suitable for the type of reflector, this type is happy with the tasks of writing, reporting and analyzing something in depth.

In the next stage, namely the jurisprudence technique in which students confront different values first, so that a debate occurs to defend the values of each group. The dialogue that occurs will train students to see problems from different points of view. At this stage, the reflector type may not appear dominant, because they are the type who prefers to observe in the discussion. But at this stage the reflector type digs up more information and develops a mindset.

Based on the explanation above, it is known that the VCT learning stages provide more opportunities for reflector types to learn in a way they like. This type of reflector is appropriate to learn with the VCT learning model because in VCT learning, students carry out more investigations and provide more opportunities for students to work independently and require good thinking and observation in their learning. 
c. Differences in Civics Learning Outcomes of Students Who Have Pragmatic Learning Styles Taught with the VCT Learning Model Compared to those Taught with the Direct Instruction Model

Based on the results of the hypothesis test, it is concluded that there is no significant difference in the learning outcomes of the pragmatic type students who are taught using the VCT learning model and those who are taught using the DI learning model. The discussion of these conclusions is explained as follows. Pragmatic types learn more easily if they can relate the material they learn to solve everyday problems. They learn more easily if they are shown a technique of doing something with real practice that provides real benefits in their lives. This type also likes to be given the opportunity to try something and practice expertly. Enjoy learning from someone who can be emulated, a successful person, with a proven track record.

Conversely, this type will have difficulty learning if learning is not directly related to what is needed, cannot see the relevance and practical advantages. They will get bored with learning that is very organized and far from reality. There is no practice and clear instructions for doing something. Not getting enough appreciation in learning activities. In the VCT learning model, which emphasizes the inculcation of values in each stage of learning, this type tends to be passive, because values tend not to provide a picture of practical benefits in real life. In contrast, in the DI learning model, the pragmatic type tends to capture learning more easily because the DI learning model is basically suitable for material in the form of procedures, and the pragmatic type can directly see the practical benefits of a material. In addition, there is a demonstration stage where pragmatic type students can see firsthand demonstrations and modeling carried out by the teacher.

Furthermore, this type learns better if it is given the opportunity to gain knowledge from trusted speakers, and is given modeling or demonstration. Adult learning is more appropriate with this type because the principle of adult learning likes to share information, experiences and seek inspiration from other people, especially successful people, so that this type is able to take examples and examples from the success of others.

\section{Conclusion}

There is an influence of the interaction between learning models and student learning styles on learning outcomes, with a value of $F=13.82$ and a value of Sig. 0 . The learning outcomes of students who have a reflector learning style that are taught with the VCT learning model are higher than those taught with the DI learning model, with the average value of student learning outcomes who have a reflector learning style who are treated to the VCT learning model (35.63) higher than the average learning outcomes of students with a reflector learning style treated with the DI learning model (27.04).

There is no difference in the learning outcomes of students who have a pragmatic learning style who is taught with the VCT learning model and those taught with the DI learning model with the VCT learning model (30.63) The learning outcomes of students who have a reflector learning style who are taught with the VCT learning model are higher than students who are taught with the VCT learning model, with an average learning outcome of students who have a reflector learning style who are treated to the VCT learning model $(35,58)$ and the average student learning outcomes with a pragmatic learning style treated with the VCT learning model (30.63).

The learning outcomes of students who have a pragmatic learning style who are taught with the DI learning model are higher than students with the reflector learning style who are taught using the DI learning model with the average learning outcomes of students 
who have a pragmatic learning style who are treated to the DI learning model $(32,27)$ and the average student learning outcomes with a reflector learning style treated with the DI learning model (27.04).

\section{References}

Ahmadi, Lif Khoiru and Sofan Amri. (2011). Paikem Gembrot, Jakarta : Prestasi Pustakarya.

Amri, Sofan. (2010). Konstruksi Pengembangan Pembelajaran. Jakarta : Prestasi Pustaka.

Anderson \& Krathwohl. (2001). A Taxonomy for Learning, Teaching, and Assessing. New York: Addison Wesley Longman, Inc.

Arends, Richard I. (2008). Learning to Teach (terjemahan). Yogyakarta : Pustaka Pelajar. Bahar, Asmaniar. (2008). Penilaian Ranah Afektif Pembelajaran PKn melalui Model Value Clarification Technique (VCT) Permainan. Jurnal Pembelajaran,Vol.30,No.2.

Bigge, Morris L. (1982). Learning Theories For Teachers. New York: Harper \& Row.

Charles, D.T. (1980). Individualizing Instruction. London: Mosby Company.

Cullingford, Cedric. (1995). The Effective Teacher. London: Cassel.

Davis J. (1989). On Matching Teaching Approach with student Learning Style: Are We Asking the Right Question. (Memphis, TN: University of Memphis.

Departemen Pendidikan Nasional. (2003). UU RI No. 20 Tahun 2003 tentang Sistem Pendidikan Nasional. Jakarta: Depdik nas.

Depdiknas. (2007). Kurikulum Berbasis Kompetensi Mata Pelajaran Kewarganegaraan. Jakarta:Depdiknas.

Dimyati \& Mudjiono. (2006). Belajar dan Pembelajaran. Jakarta: Rineka Cipta.

VCT. Bandung : Lab.PMPKN IKIP Bandung.

Djamarah, Syaiful Bahri. (2011). Psikologi Belajar. Jakarta: Rineka Cipta.

Gagne, Robert M. \& Marcy P. (1989). Driscoll. Essentials of Learning for Instruction. New Jersey: Prentice Hall.

Ginting, S. et al. (2020). The Effectiveness of Citizenship Education (PPKn) Module on Environmental Love Material by Using Example Non Example Learning Model. Budapest International Research and Critics in Linguistics and Education (BirLE) Journal. P. 647-661.

Honey \& Mumford. (1999). Understanding Your Learning Styles. Psych Press. diakses dari http://www.psychpress.com.au. pada tanggal 15 Agustus 2015.

Ichas, Hamid Al-lamri \& Tuti Istianti Ichas. (2006). Pengembangan Pendidikan Nilai dalam Pembelajaran Pengetahuan Sosial di Sekolah Dasar. Jakarta : Dirjendikti.

Joyce, Bruce et.al. (2011). Models of Teaching (terjemahan). Yogyakarta : Pustaka Pelajar.

Kemp, Jerrold E. (1977). Instructional Design A Plan for Unit and Course Development. California: David S. Lake Publishers.

Khairiah, N and Nurzannah. (2020). Many Ways to Internalize Islamic Values Implemented in Indonesia. Budapest International Research and Critics InstituteJournal (BIRCI-Journal). P. 3956-3967.

Marjoribanks, Kevin. (1991). The Foundation of Students' Learning. New York: Pergamon Press.

M, Nur dan Kardi, S. (2000). Pengajaran Langsung. Surabaya: Pusdat Sains dan Matematika Sekolah Program Pasca Sarjana UNESA.

Muijs, Daniel \& David Reynolds. (2008). Effective Teaching. Yogyakarta: Pustaka Pelajar. 
Muron, Faisal Sadam. (2015). (repository.upi.edu). diakses 17 Agustus

Muslih, Masnur. (2011). Pendidikan Karakter Menjawab Tantangan Krisis Multidimensional. Jakarta: Bumi Aksara.

Narmoatmojo, Winarno. (2010). Pendidikan Kewarganegaraan Berbasis Nilai Lokal: Identifikasi dan Implementasi.Proceeding. Seminar Nasional "Aktualisasi Pendidikan Karakter Bangsa. Bandung. 5 Nopember.

Nasution. (2008). Berbagai Pendekatan dalam Proses Belajar Mengajar. Jakarta: Bumi Aksara.

Prashnig, Barbara. (2007). The Power of Learning Styles. Jakarta: Kaifa.

Romiszwoski, A.J. (1981). Instructional Design System, Decision Making in Course Planning and Curriculum Design. London: Kogan.

Purwanto, Ngalim. (2000). Psikologi Pendidikan. Bandung: Remaja Rosdakarya.

Sanjaya, Wina. (2012). Strategi Pembelajaran Berorientasi Standar Proses Pendidikan. Jakarta: Kencana.

Santrock, John W. (2004). Educational Psychology. New York: McGraw-Hill Co.

Sardiman. (2000). Interaksi \& Motivasi Belajar Mengajar. Jakarta: Rajawali Pers.

Slameto. (2010). Belajar dan Faktor-Faktor yang Mempengaruhinya. Jakarta: Rineka Cipta.

Somantri, Muhammad Numan. (2001). Menggagas Pembaharuan Pendidikan IPS, Bandung: Remaja Rosda Karya.

Suprijono, Agus. (2010). Cooperative Learning Teori \& Aplikasinya, Yogyakarta: Pustaka Pelajar.

Suyono \& Hariyanto. (2012). Belajar dan Pembelajaran. Bandung: Remaja Rosdakarya Offset.

Syaharuddin. (2016). wordpress.com/2012/07/05/model-pembelajaran-mediatif-oleh-iwanet al, diupdate tanggal 28 Januari.

Taniredja, et al. (2011). Model-Model Pembelajaran Inovatif. Bandung: Alfabeta.

Uno, Hamzah. (2008). Orientasi Baru dalam Psikologi Pembelajaran. (Jakarta: Bumi Aksara) 